Received: 13 August 2017

Accepted: 4 September 2017

Additional information is available at the end of the article.

KEYWORDS: lead poisoning; tuberculosis; shoemaking; butchery; economic depression; migration; Suffolk; poverty

\section{Bricks in the wall: family tree research can uncover useful historical information}

\author{
Trevor J. Cooper
}

\begin{abstract}
Case studies of two branches of the Read family demonstrate the value of genealogical research as exemplars of historical scholarship, as well as contributing new evidence for further research: bricks in the wall. Wider research into sources beyond the usual births, marriages, deaths and parish records provides information relevant to broader historical research. The family case studies exemplify the economic factors driving the movement of people from rural to urban areas which was typical of the prolonged agricultural depression in Britain of the 1820s to 1850s, a period in which the economy was struggling to adjust to the post-Napoleonic War period. These case studies provide examples of the responses of a tenant farmer and a family of shoemakers. Their subsequent experience of migration to London from Suffolk reflects the problems of this period. One branch established a successful butchery business, but suffered the ravages of a very urban disease: tuberculosis. The other branch shows the poverty that formerly well-paid artisan shoemakers suffered with the industrialisation of their craft.
\end{abstract}

\begin{abstract}
Introduction
Research into the Read family was conducted for the usual family history reasons. It uncovered information which touched on much wider socio-economic and medical issues which are illustrative of the major problems associated with urbanisation and industrialisation. The two branches of the family are related (see Figure 1), and originate from Badingham, Suffolk, but their experiences of moving to London are different. There is evidence to show a much higher rate of death by tuberculosis among the branch who were involved in the butchery trade (George Read's family). This supports research into this disease and whom it infected. The other branch (Joseph Read's family) shows the impact of industrialisation, which drove the family members into marginal economic activity as street traders (costermongers), and the poverty which followed. As a consequence of this, a female member of the family engaged in dangerous work which killed her. This opens up further issues related to Victorian concerns about women working, factory legislation and safety at work. In both cases there is evidence to show the decline of the family because of their move to London.
\end{abstract}

\title{
George Read
}

The first branch of the family to move to London was that of George Read, who was born in 1790 (see Figure 2). (His baptism does not appear on available transcriptions, which underlines the value of consulting the original sources. $)^{1}$ He seems to have been prosperous and successful. The baptism records of his children track his career: in 1813, he was a wheelwright ${ }^{2}$; after 1818, he was an innkeeper ${ }^{3}$; and at the baptism of his youngest child in 1834 he was listed as a farmer. ${ }^{4}$ In 1832 he declared a business partnership dissolved due to the debts of his partner, Robert Moore, also a farmer. ${ }^{5}$ George moved to London in company with his wife and children sometime after the baptism of his youngest child in 1834 at Badingham, but before 1841. It is likely that there were business difficulties associated with the prolonged agricultural depression of the 1820s to 1850 s which led to George seeking better prospects for himself and his family in London: the contents of the farm were sold by auction on 7 July $1838 .^{6}$

By the 1841 census, George was living in St Giles in the Field, London (Bloomsbury). ${ }^{7}$ This was largely a slum area at this time, with the usual problems of overcrowding and insanitary conditions. As London grew in the eighteenth and nineteenth centuries, so did the parish's population, rising to 30,000 by 1831 . The Rookery between the church of St Giles and Great Russell Street was one of the worst slums in Britain, a site of overcrowding and squalor; a semi-derelict warren. From affluence in the eighteenth century, the area had declined rapidly as houses were divided up, many families sharing a single room. Irish Catholic immigrants seeking to escape desperate poverty took up residence

( 2017 The Author(s). This is an open access article distributed under the terms of the Creative Commons Attribution License (http://creativecommons.org/ licenses/by/4.0/) 


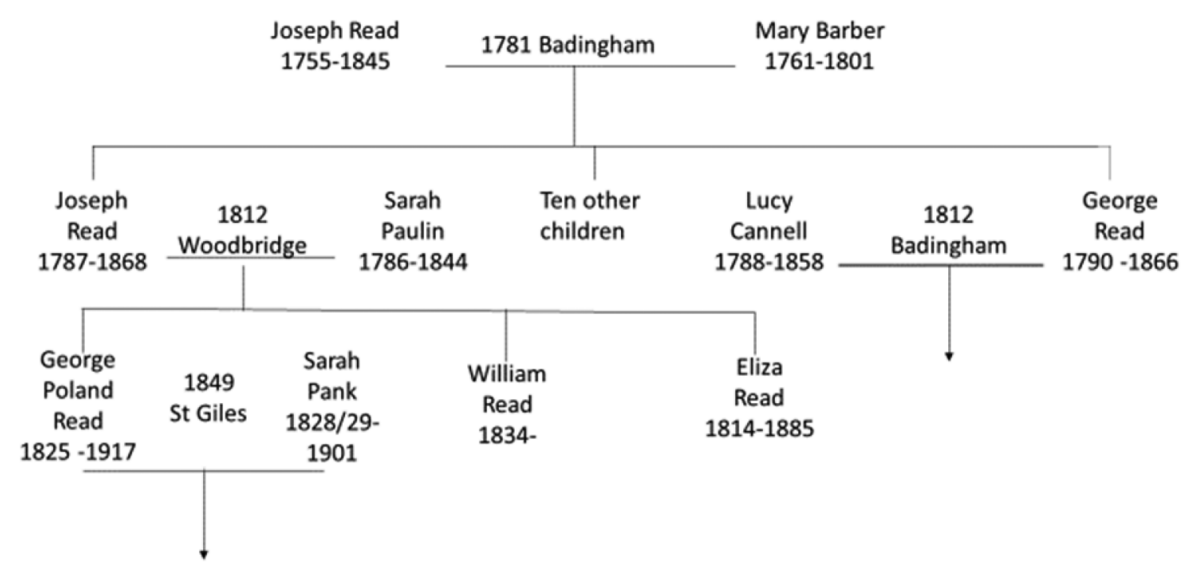

Figure 1. Relationship between the two Read families.

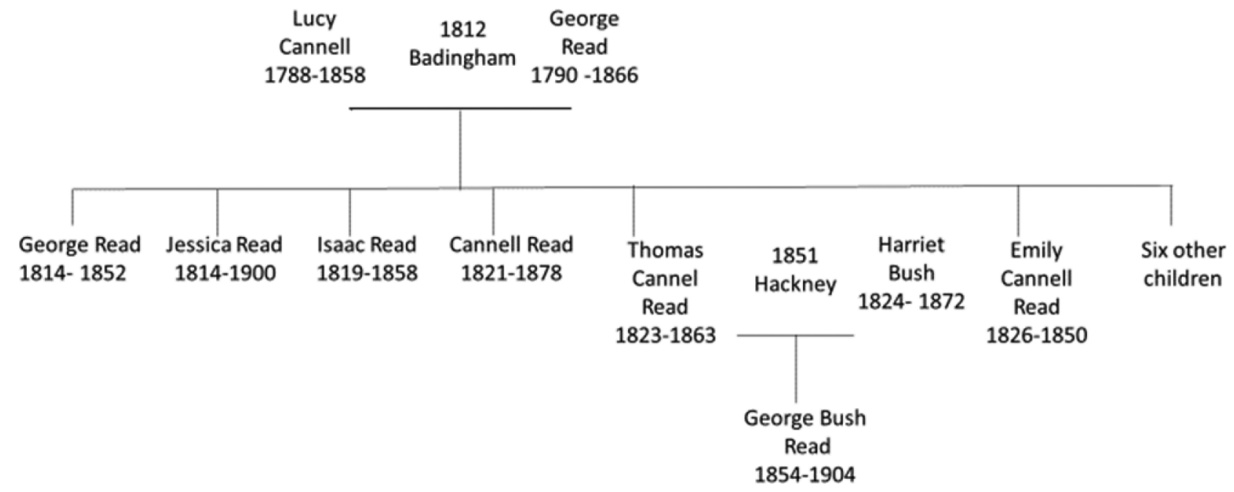

Figure 2. The butchery Reads.

and the slum was nicknamed 'Little Ireland' or 'The Holy Land'. It was a maze of gin shops, prostitutes' hovels and secret alleyways. William Hogarth, Thomas Rowlandson, and Gustav Dore, among others, drew the area, and novelists Henry Fielding and Charles Dickens referenced it. However, George appears to have taken a lease on a property in one of the 'better' areas, Little Coram Street ${ }^{8}$ near Russell Square, and was renting out rooms in a formerly large house to four other families, twelve people in addition to himself, his wife and four of their children which included his son George (born in 1814). ${ }^{9}$ George and his son gave their professions as butchers. George senior, however, was not apprenticed as a butcher, and should be understood as the proprietor and entrepreneur who had established the butchery businesses and invested in his two sons' butchery trade.

This move must have been successful because by the 1851 census ${ }^{10}$ George senior was living in the upmarket area of The Strand, St Clement Danes in the City of London, working as a master butcher, assisted by his wife Lucy, his son Isaac (born in 1819; Isaac Read died on 23 December 1856 at his father's house - 4 Barnards Inn, Holborn, London, and was described as 'recently returned from Australia') ${ }^{11}$ and daughter Catherine (born in 1834). ${ }^{12}$ Nearby at 84 Chancery Lane his son George was running a butchery business with his brother Thomas Cannell Read (born in 1823) ${ }^{13}$ and sister, Jessica Read (born in 1818)..$^{14}$ The family continued to operate the butchery until after the 1871 census when their fortunes changed and they ceased to operate as butchers. In 1861, after the death of his brother in 1852, Thomas was running the butchery ${ }^{15}$ and appeared in the Westminster Rates Books until his death in $1863 .{ }^{16}$ In $1871^{17}$ his widow Harriet was running the business, assisted by their son George Bush Read (born in $1854^{18}$ ). However, after her death in $1872^{19}$ and by the time of the census in $1881^{20}$ this son George was working as a salesman's clerk and lived in Islington until his death in 1904.

By 1861 George was living in the prestigious No. 4, Barnard's Inn in the City of London, as a 'proprietor of properties' (i.e., a landlord); he was aged seventy-one and retired. ${ }^{21}$ His wife's death certificate of $1858,{ }^{22}$ and his own of $1866,{ }^{23}$ described him as a 'gentleman'. Barnard's Inn was 
a large ancient building which, by 1830 , had become a set of residential apartments. It had previously been used by practising lawyers as an Inn of Court. It is now part of Gresham College.

Quite how the family was able to establish a business in upmarket areas of London as 'master butchers' is not known. The father, George, had several previous occupations as we know, and only in London in 1841 did he appear as a butcher. As a farmer, he would have had some contact with the trade, but not as a practitioner. The only known connection to the trade is through his son, Thomas Cannell Read who in the 1841 census was working for one Joseph Brown at the Thoroughfare, Halesworth, Suffolk, who was a butcher. ${ }^{24}$ It is George junior who seems to be the head of the butchery business in Chancery Lane in 1851, and it is possible (but there is no evidence) that he had been apprenticed earlier to a butcher.

In Badingham churchyard, outside the south door among several other gravestones of related members of the Read family, is the gravestone of the younger George Read. This opens the door on the issue of tuberculosis infection within the butchery trade:

Sacred to the memory of George Read late of Chancery Lane, London eldest son of George Read formerly of this parish who died July $21^{\text {st }} 1852$ aged 38 years. In my distress I cried unto the Lord and he heard me. Psalm CXX.

The reference to Chancery Lane catches the attention as it is unusual for a rural churchyard. There is an item in the Suffolk Chronicle to the effect that he died at Dennington (a village in Suffolk, near to Badingham) on 21 July and was '... late of Chancery Lane, London and formerly of Badingham ... highly respected and deeply regretted by all who knew him. ${ }^{25}$ In the short time he lived at Dennington, he made a mark locally, given the comments made. He had moved to London with his father and siblings in the mid to late 1830s. He was also recorded in the 1851 census for the Strand, ${ }^{26}$ and was dead fourteen months later in Dennington. His father George was present at the death and gave his address as 'Strand, London'. ${ }^{27}$ The death certificate records his trade as 'butcher' and his death as due to 'phthisis pulmonalis', a wasting disease better known as tuberculosis. He had suffered the illness for three years.

Tuberculosis was widespread from the late eighteenth to the early twentieth century. It proliferated due to industrialisation, urbanisation and the concomitant living conditions of poor air quality, lack of sanitation, overcrowding, poor nutrition, overwork and prevailing poverty. ${ }^{28}$ It was also a major killer in rural areas, but has come to be seen as an urban disease. It was highly infectious and spread by 'aerosol droplet infection' from coughs and sneezes, although at the time this was disputed by physicians, many of whom preferred the notion that it was an 'innate susceptibility' of the individual. ${ }^{29}$ It was also called 'consumption' because victims were almost literally consumed. ${ }^{30}$ It is likely that George had returned to Suffolk for the cleaner air in an attempt to treat the disease. The prevailing treatment was clean air and bathing, to be taken at the seaside or the country, but away from the polluted air of the cities (Switzerland began to be a popular destination for consumptives). Knowing that makes the quotation from Psalm CXX on the gravestone seem very apposite.

Robert Koch discovered the bacterium mycobacterioum tuberculosis which caused tuberculosis in 1882, finally explaining the cause of the disease, and this confirmed what other researchers from the 1860s had thought but had not proven. He established that it was contagious, and transmissible between humans both by ingestion and inhalation. This led to more rigorous inspections of slaughterhouses by Medical Officers of Health, and ultimately to the pasteurisation of milk. However, while Koch also established that the human bacterium he had identified was very similar to the bovine form, mycobacterium bovis, he rejected the work of other researchers such as the French physician Jean-Antoine Villenin, who argued that it was transmissible from cattle to humans. As Roy Porter says, 'In this he (Koch) was wrong'. ${ }^{31}$ Porter emphasises the importance of proximity to animals in an urban environment, pointing out that we share sixty-five diseases with dogs. He argues that 'cattle provided the pathogen pool with tuberculosis and viral poxes like smallpox' and much later bovine spongiform encephalopathy (BSE). ${ }^{32}$ Recent research confirms that while mycobacterium is a human form, the bovis form has a broad range of hosts, including humans, and is defined as zoonotic because it can cross species, much as the so-called 'bird flu' can. ${ }^{33}$ It is suggested that it was a particular occupational hazard for people who worked with animals, such as farmers, butchers and slaughterhouse workers, because of their increased exposure to cattle carrying mycobacterium bovis or bovine tuberculosis. ${ }^{34}$ The bacterial strains were very similar, and workers are exposed to infectious aerosols from the living animals and their carcasses. ${ }^{35}$

Tuberculosis seems to have taken a toll on this family. Perhaps the occupational hazard of butchery work compounded the more common causes of urbanisation and associated conditions. Several members of the family died of the disease in addition to George in 1852. All of them were butchers by trade. The disease took many forms which made it difficult for physicians to understand, ${ }^{36}$ as is evidenced by the following deaths. George's sister Emily Cannell Read died in 1850 of 'nepturia and phthisis', i.e., kidney disease and tuberculosis. ${ }^{37}$ In 1856, George's brother Isaac died of 'disease of the liver and phthisis', i.e., liver disease complicated by tuberculosis. ${ }^{38}$ In 1858 George's mother, Lucy, died of phthisis after only seven weeks. ${ }^{39}$ George's brother, Thomas Cannell Read, died on 7 February 1863 of 'phthisis pulmonalis', i.e., the most common form of tuberculosis affecting the lungs. ${ }^{40} \mathrm{He}$, like George, had left London for cleaner air, and died at a sanatorium in Penzance: his body was returned to London where he was buried 
on 16 February 1863 at St James' church, St Pancras, Camden. ${ }^{41}$ Cannell Read, George's brother, died in 1878 of 'empyema tubercular meningitis', i.e., pleurisy and tuberculosis of the brain spread from the lungs. ${ }^{42}$ The Ipswich Journal of 1 October 1878 in its death notices observed that he was the 'son of the late George Read, of the Strand and formerly of Badingham'. 43

\section{Joseph Read}

The other branch of the family who were nephews and niece to the elder George Read made the move to London during the 1840s (see Figure 3). It may be that they followed George's move as migrants do today by moving where there are family, friends or people of similar culture and trades. ${ }^{44}$ There is no evidence of contact between the two branches in London, only the circumstantial evidence that they both started their new life in the St Giles area. There is no evidence to suggest that this branch moved at the same time; they may have migrated individually.

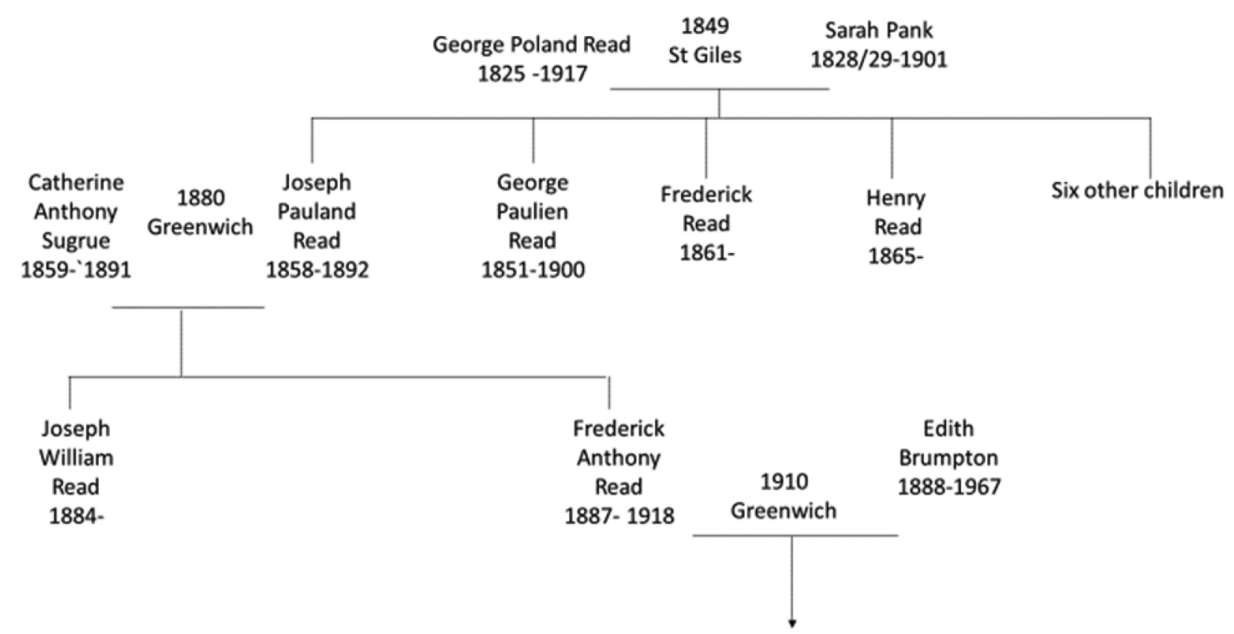

Figure 3. The shoemaker Reads.

This branch would also have been motivated by the depression in the countryside and within their shoemaking trade, which was collaterally affected. The father, Joseph Read $\left(1787^{45}-1868^{46}\right)$, was a cordwainer, and was brother to the elder George Read. He was relatively successful. He was married to Sarah Paulin ${ }^{47}$ (who was the daughter of Lt John Paulin of Landguard Fort, a coastal battery at Felixstowe, Suffolk) at Woodbridge in Suffolk on 24 December $1812 .^{48}$ This was a status marriage, and the connection is mentioned on their gravestone in Badingham churchyard. He was in business as a cordwainer in both Badingham and the nearby township of Woodbridge.

In 1825, Joseph was imprisoned and taken to the Court for the Relief of Insolvent Debtors, which was held at Ipswich, by his creditors for recovery of these debts. (Such courts had been introduced by Act of Parliament in 1813, to relieve the overpopulated prisons of holding large numbers of debtors. Debtors being pursued by creditors could appeal to the court to release them, if they could convince the court and their creditors that they could repay the debts. Debtors continued to be imprisoned until 1869, subject to settling the debts or if a petition for relief was accepted by the court.)

It seems that Joseph had shop premises in Woodbridge while also being based in Badingham, because he is described in the Suffolk Chronicle notice of his intended appearance at the court as '... heretofore of Woodbridge ... Cordwainer, Jobber and Shopkeeper'. ${ }^{49}$ The Bury and Norwich Post later reported that Joseph Read of Badingham was 'discharged', which meant he was released from prison because he was able to reach an agreement with his creditors through the court. ${ }^{50}$ It may be that Joseph had closed his premises in Woodbridge (hence the description).

Supporting Joseph's business presence at Woodbridge, and demonstrating the difficulties affecting the shoemaking business more widely, is a similar case in 1821 concerned with the debts of John Carr, cordwainer and shoemaker of Woodbridge. Joseph Read acted on his behalf by having an open deed of assignment (the arrangement to repay the debts) at his own premises for Carr's creditors to read and sign to press their claim. ${ }^{51}$

*There is no record relating to Joseph Read at this time in the County or Ipswich Quarter Sessions, B105/2/64; Insolvent Debtors' Accounts and Papers, C/2/9/1/7 and C2/9/1/7/26/2; or the Woodbridge Gaol Index, B106/3/8.1-8.4. 
It would appear that the shoemaking industry was suffering from the prolonged economic recession in the period after the Napoleonic Wars, which caused huge upheaval and distress, due to peacetime dislocation of the economy together with the extremely bad weather affecting agriculture across this period. The prolonged depression in agriculture into the 1850s would have seriously affected Suffolk and its business economy. The depression in agriculture led to much unrest in rural areas and ultimately to the repeal of the protectionist Corn Laws in 1846 to alleviate poverty and rebalance the economy in favour of industry. The poor rates during this time rose extraordinarily to meet the consequent poverty and distress, which placed heavy burdens on those like Joseph, who paid the poor rates. These factors were influential in leading to the reform of the relief of the poor in the New Poor Law of 1834 (the notorious workhouse system). A former apprentice cordwainer of Joseph's, David Read (probably a nephew indentured in 1817), was in financial difficulties in 1837 when he was 'removed' from Framlingham to his legal place of settlement at Badingham, for the parish to support him and his family from their poor rates. ${ }^{52}$ Joseph's brother, Charles $^{2}$ (baptised in $1792^{53}$ ), was a cordwainer, but after 1841 his occupation was given as a 'carrier'.

Joseph's two sons and a daughter migrated to London in the 1840s. One son, George Poland Read (c.1825 $5^{54}$ to 1917; his death certificate gives his age as $92^{55}$ ), appeared in the 1851 census living in St Giles in the Fields, London; the property was shared with six other families, who were all artisans. ${ }^{56}$ He was married with one child and was working as a shoemaker. He had married Sarah Pank, the daughter of a shoemaker, in 1849 in St Giles. ${ }^{57}$ He was living on the outskirts of the notorious Rookery slums at Smarts Buildings which itself was a courtyard infilled into a space between two streets, Newton Road and Coal Yard. ${ }^{58}$

George's brother, William (baptised in 183459; all census records give his birth year as 1831) does not appear in the 1851 census in London or Suffolk. He does appear in the 1861 census in Greenwich, working as a shoemaker, with his wife and a child born in 1851 in St Giles. The birth of the daughter proves he was in London in 1851, if not in the census. George and William's elder sister Eliza was also in London and married another shoemaker who was from Suffolk at Stepney in $1845^{60}$ (there is no baptism record for Eliza. The relationship is established by the 1861 census where she is living with her father Joseph as his housekeeper, using her married name of Archer). ${ }^{61}$ Eliza and her husband had returned to Suffolk by $1851 .{ }^{62}$

The 1861 census shows George and William having moved out of St Giles to East Greenwich, working as shoemakers. ${ }^{63,64}$ Greenwich was substantially overcrowded and the housing was of poor quality. West Greenwich was an area which had grown around the original town's parish church of St Alphege. East Greenwich was an area developed on the Greenwich Marshes in the early to mid nineteenth century as housing for labourers. By 1841 this was very much a working-class community where most of the men were doing unskilled work; some on the land, some on the river and a few in the factories. It had never been a suburb from which the middle class had moved as the workers came, like St Giles and West Greenwich; it was a place to which families moved as work and houses became available. It had a large Irish immigrant population on account of the famine in Ireland, a period of mass starvation and disease between 1845 and 1852, when approximately one million people died and a million more emigrated. ${ }^{65}$

William continued to work as a shoemaker, along with his children in Greenwich until 1881. After 1881, there is no further trace of him or his family. The censuses continued to list George as a cordwainer or shoemaker until 1871. After that he was listed as a costermonger in 1881, a greengrocer in 1891 and then as a 'cord winder' (a corruption of 'cordwainer') in 1901. The 1911 census does not record his occupation. His death certificate in $1917^{66}$ states that he was 'formerly a cooper': another change of occupation. His career seems to reflect what happened to shoemaking during the nineteenth century. From being a profitable artisan craft, it was increasingly mechanised, and by the late nineteenth century was factory-based. Mechanisation would have reduced his work and income, and led him into greengrocery and costermongering, which was difficult marginal work.

Only George's son George (born 1851 187 ) continued to work as a shoemaker (shown on his death certificate ${ }^{68}$ ); his other three sons joined him working as costermongers. This move into marginal work is characterised by poverty, the workhouse and early death. George's son Joseph (born in 1858) ${ }^{69}$ worked as a general dealer and costermonger. He died in the Greenwich Workhouse Infirmary on 9 September 1892, aged thirty-three. Prior to this, he had been resident at the Lunatic Asylum at Maidstone. ${ }^{70}$ He was admitted there on 30 November 1888 as a 'melancholic', i.e., depressive, and had been suffering for four months. The admission record says that he was there because of 'imprisonment', which refers to his actual committal there. His wife Catherine seems to have sought help, which led to a medical certificate being signed by Walter E. Boulter, superintendent ${ }^{71}$ of the workhouse infirmary, as the basis for committal. He was admitted on the authority of E. N. F. Fenwick who was a Justice of the Peace for Greenwich, who signed the committal order because Joseph was considered a suicide risk and a danger to others. (Edward N. Frederick Fenwick was a barrister who dealt with petty crimes in the police court.) On admission to the asylum, ${ }^{72}$ and previously when living with his family, he was under the delusion that his food was being poisoned by his wife. He could only be persuaded to eat with great difficulty. He also thought that people suspected him of being Jack the Ripper, and feared being attacked on the streets on this account, as people called him such in the street. He appears to have 'dwelt very much upon the accounts he has heard of Jack the Ripper ${ }^{73}$ 
who was active in 1888, killing five women between August and November. He continued to refuse to eat in the asylum, and had to be forcefed on one recorded occasion.

To compound the tragedy, his wife Catherine died on 18 June $1891^{74}$ of lead poisoning caused by her work at Pontifex's Millwall Lead Works. ${ }^{75}$ She had been employed to extract the highly toxic (but valuable and useful) white lead from the beds. White lead was formerly used as an ingredient for lead paint. It was also used as lubricants for bearings, lathes in machine shops and waterproofing wooden ships. Catherine would have been involved in scraping the white lead powder from lead blocks which had been boiled in vinegar in the beds to corrode them and produce the lead carbonate. At the coroner's inquest on 23 June, her father-in-law George identified her body and said that he had not seen his daughter-in-law for three weeks, when 'she thought she was suffering from lead poisoning and looked pale and bad'. ${ }^{76}$ It was reported that she complained of headaches after leaving work. A witness from her lodgings reported that Catherine had to work even when she was ill, 'to keep her and her child'. She appears to have consulted the doctor provided by Pontifex during April, and continued to work until 23 May, when she returned from the pier for the river crossing from Greenwich to the lead works as she was 'too ill to work'. She was reported to have 'retched all day, and to have brought up pieces of lead'. The inquest heard that she 'retched very much, and complained of her head. Her gums were very blue and swollen, and she could not take nothing but cold water."77

Catherine had worked at the lead works for some eleven years, 'on and off'. It was relatively well-paid work for women at the time, at 12 to 14 shillings a week; but not a living wage. The work attracted many women workers. She spoke of the work as 'killing work'. A witness at the inquest said that the most dangerous work was 'in the stoves' which is where she worked gathering the white lead carbonate from the boiled lead metal. While the company followed the health and safety rules current at the time, there were several reported deaths of other young women by lead poisoning. The lead powder was ingested in the lungs, in the saliva and through the skin. The company had rules which workers were fined for not following. She was fined for not wearing her respirator on one occasion in 1890, but not subsequently. Respirators were available at this time, but were really crude face masks with a cotton filter. Workers were required to wear respirators because the lead powder 'blew about'. They had to wear caps (but not overalls - they were required to brush their clothes instead!) and to drink 'acid water' (lemonade) frequently, which was provided. They were also required to wash before eating, and bathe once a week. The latter rule was unrealistic, given the housing conditions for workers like Catherine. Some of these rules only became law in 1891, by which time Catherine would have been heavily exposed to the poison over the previous ten years. By 1894 , workers were provided with overalls. ${ }^{78}$ The inquest into Catherine's death heard that some workers were badly affected within two weeks. ${ }^{79}$

There were several reported deaths by lead poisoning at this time. The Daily Chronicle began a campaign featuring the deaths of women workers in the lead industry, with a series of sensational articles such as 'White cemeteries; massacre of the Innocents' ${ }^{80}$ These accounts were reported in newspapers across the country. The newspaper argued that women without any alternative means of support were forced to accept such employment because of their circumstances. The Factory Inspectorate took up the issue, which led to stricter rules in 1898 to prevent the inhalation of the dust. The new rules also led to the exclusion of women from parts of the process. In part, this was a moral issue about the suitability and proper place of women in the workplace, and also one of increasing state intervention in factory conditions. The removal of women led to an increase in the number of male workers dying of lead poisoning, which suggests that the new regulations were themselves not adequate. ${ }^{81}$

The company employed the services of a doctor who regularly examined the workers. Catherine had visited this doctor on 11 and 12 April and was prescribed some medicine. She applied to go into the workhouse infirmary on 25 May, and died there on 18 June. The inquest heard that on 26 May she contracted influenza with a temperature of 104, 'and could not take much nourishment'. ${ }^{82}$ It also heard that her symptoms were 'a blue line on her gums, constipation, irritation of the stomach, a sweet taste in her mouth, and griping pain', ${ }^{83}$ which it concluded were consistent with lead poisoning. (The blue line on the gums was an indicator of exposure to lead sulphide (white lead), but did not necessarily mean poisoning. ${ }^{84}$ ) The inquest went on to say that she developed 'brain Symptoms' and had an 'epileptic kind of fit, and died comatose' ${ }^{85}$ The inquest concluded that she 'died from influenza following lead poisoning'. ${ }^{86}$ It also concluded that she could have been treated for the lead poisoning if she had not been suffering from influenza at the same time. This seems to exonerate the employers by blaming the victim for having influenza, and ignores the deleterious effects of lead poisoning on a person's health. It conforms to the practice of influenza being the common cause of death following other illnesses given on death certificates.

In the 1891 census, Catherine was living with their youngest son Frederick (born in 1887 ) ${ }^{87}$, while their elder son Joseph aged seven ${ }^{88}$ was lodging with his uncle, Joseph's brother, Frederick. The young Frederick was spared the workhouse after his mother's death as he went to live with his uncle Henry, another brother of Joseph. There is no record of his admission to the workhouse. Both uncles, Henry and Frederick, were married, but without children. 
Catherine died while her husband Joseph was still in the asylum. Joseph's melancholia and delusions continued, but he periodically showed signs of improvement. This allowed him to be discharged into the 'care of friends' on 5 December 1891 as recovered. ${ }^{89}$ He probably was not recovered, and was unable to cope after the earlier death of his wife. He was admitted to the workhouse on 4 July 1892 as 'destitute' ${ }^{\prime 90}$ and he died a few months later on 9 September 1892, aged only thirty-three. ${ }^{91}$ It is possible to speculate about the death of Joseph. He died of cardiac arrest caused by dropsy (or pulmonary oedema). ${ }^{92}$ This can occur due to heart problems; it can also be caused by the inhalation of toxic chemicals. When admitted to the asylum, he reported 'that at home he noticed strange powder about the place, and that this powder was in his food, and that it caused a bad taste in his mouth'. This could be lead poisoning (like passive smoking) from his wife, who would have brought home the white lead powder on her clothes and brushed them as the factory required. (A symptom of lead poisoning, unsurprisingly, is a metallic taste in the mouth.) The asylum noted that Joseph had a scar on his head, 'of a rather severe wound' and a dull pressing pain at the wound. Unfortunately, the asylum did not engage with whether this had an effect on his mental health. The asylum observed that his 'expression was vacant \& listless, pupils dilated \& sluggish' and that he took 'some little time to collect his thoughts, very childish \& simple in his remarks' ${ }^{93}$ This is all consistent with both a brain injury and lead poisoning. Joseph may have suffered both.

\section{Conclusion}

The background research into both branches of the Read family has provided evidence to support, and to add to, wider historical research; in particular, the typical migration to the towns, driven by the effects of economic depression. With one branch of the family, men 'on the tramp' moved from their home parish in search of work. There is some evidence here of people sticking together to find work and accommodation, given the marriages to the daughters of other shoemakers. It has also shown the negative effects on artisan shoemakers of the increasing mechanisation of their trade due to industrialisation, which was an experience in common with the better-known weavers and stockingmakers.

The case studies exemplified people having to find work where they can, in this case taking marginal employment as costermongers. Catherine Read took up dangerous work at a lead works to support her family. While there is research into the cases of young women dying through their work in the white lead industry, this research has highlighted another issue: that of secondary contamination with toxic chemicals, which is evidenced by the mental illness of her husband, Joseph Read.

The research into the other branch of the family who established butchery businesses has provided evidence of a higher mortality within that family by various forms of tuberculosis. In contrast, the poorer shoemaking branch where mortality from tuberculosis might have been expected only has one known fatality by the disease that is known. (George Paulien Read died of phthisis empyema (tuberculosis) in the Greenwich Union Workhouse. $)^{94}$ This provides some support for the argument that this was an industrial disease, and an occupational hazard, in common with other diseases related to particular occupations.

\section{Citation information}

Cite this article as: Cooper, Trevor J. (2017) Bricks in the wall: family tree research can uncover useful historical information. Journal of Genealogy and Family History. 1(1). https://dx.doi.org/10.24240/23992964.2017.030105

\section{Acknowledgements}

With thanks for their research to Mark Ballard, Kent County Archives; Anne Dodds, Read family tree research; Gemma Pardue, Suffolk Record Office, and Pauline Watson, Royal Greenwich Heritage Trust.

\section{References}

1. Baptisms (PR) England. Badingham, Suffolk. 24 March 1790. READ, George. St John the Baptist, Badingham, Suffolk.

2. Baptisms (PR) England. Badingham, Suffolk. 19 March 1813. READ, George. St John the Baptist, Badingham, Suffolk.

3. Baptisms (PR) England. Badingham, Suffolk. 25 January 1818. READ, Jessica. St John the Baptist, Badingham, Suffolk.

4. Baptisms (PR) England. Badingham, Suffolk. 19 January 1834. READ, Catherine Jane. St John the Baptist, Badingham, Suffolk.

5. Bankruptcies. (1832) Perry's Bankrupt and Insolvent Gazette. MOORE, Robert and READ, George. p. 667a. Collection: British Newspapers 1700-2017. www.findmy past.co.uk.

6. Suffolk Chronicle. (1838) At Badingham Suffolk. Suffolk Chronicle. 30 June. p. 1b. Collection: British Newspapers 1700-2017. www.findmypast.co.uk.

7. Census. 1841. England. St Giles, Middlesex. HO107. PN 672. FL 8. p. 9.

8. Miller, F. (1874) Saint Pancras past and present. London: Son.

9. Baptisms (PR) England. Badingham, Suffolk. 28 February 1814. READ, George. St John the Baptist, Badingham, Suffolk.

10. Census. 1851. England. St Clement Danes, Middlesex. HO107. PN 1512. FL 119. p. 8.
11. Death announcements. (1856) Suffolk Chronicle. 27 December. READ, Isaac. p. $2 f$ Collection: British Newspapers 1700-2017. http:/www.findmypast.co.uk.

12. Baptisms (PR) England. Badingham, Suffolk. 19 January 1834. READ, Catherine. St John the Baptist, Badingham, Suffolk.

13. Baptisms (PR) England. Badingham, Suffolk. 30 May 1823. READ, Thomas. St John the Baptist, Badingham, Suffolk.

14. Baptisms (PR) England. Badingham Suffolk. 25 January 1818. READ, Jessica. St John the Baptist, Badingham, Suffolk.

15. Census. 1861. England. Liberty of the Rolls, Strand, Middlesex. RG09. PN 181. FN 76. p. 7.

16. Westminster Rate Books 1634-1900, FN 5, www.findmypast.co.uk.

17. Census. 1871. England. Liberty of the Rolls, Strand, London. RG10. PN 368. FN 5. p. 10.

18. Baptisms (PR) England. Strand, London. 12 February 1854. READ, George Bush. Births and Baptisms Transcription 1538-1975. www.findmypast.co.uk.

19. Deaths (CR) England. St Clement Danes, Middlesex. 19 December 1872. READ, Harriet.

20. Census. 1881. England. Islington. RG11. PN 229. FN 66. p. 34

21. Census. 1861. England. Barnards Inn, City of London. RG09. PN 221. FN 147. p. 10

22. Deaths (CR) England. South West London. 18 July 1858. READ, Lucy.

23. Deaths (CR) England. South West London. 14 April 1866. READ, George.

24. Census. 1841. England. Blything Union, Suffolk. HO107. PN 1015. Book 16. FN 4. p. 1.

25. Death announcements. (1852) Suffolk Chronicle. 31 July, READ, George. p. 3a. Collection: British Newspapers 1700-2017. www. findmypast.co.uk.

26. Census. 1851. Liberty of the Rolls, Strand, Middlesex. HO107. PN 1512. FN 429. p. 7.

27. Deaths (CR) England. Dennington, Hoxne, Suffolk. 21 July 1852. Read, George.

28. Nikiforuk, A. (1993) The fourth horseman. London: Phoenix. pp. 126-144. 
29. Porter, R. (1999) The greatest benefit to mankind. London: Fontana. p. 442.

30. Porter, R. (1999) The greatest benefit to mankind. London: Fontana. p. 401.

31. Porter, R. (1999) The greatest benefit to mankind. London: Fontana. p. 442.

32. Porter, R. (1999) The greatest benefit to mankind. London: Fontana. p. 18.

33. De la Rue-Domerach, R. (2006) Human mycobacterium bovis infections. Tuberculosis. 86(2). pp. 77-109.

34. O'Reilly, L. M. and Daborn, C. J. (1995) The epidemiology of mycobacterium bovis infections in animals and man. Tubercle and Lung Disease. 76. pp. 1-46.

35. Waddington, K. (2006) The bovine scourge. London: Boydell. p. 31

36. Waddington, K. (2006) The bovine scourge. London: Boydell. p. 11

37. Deaths (CR) England. St Clement Danes, Middlesex. 21 March 1850. READ, Emily Cannell.

38. Deaths (CR) England. South West London. 23 December 1856. READ, Isaac.

39. Deaths (CR) England. South West London. 18 July 1858. READ, Lucy.

40. Deaths (CR) England. Penzance, Cornwall. 7 February 1863. READ, Thomas Cannell.

41. Burials (PR) England. St Johns Church, Camden, London. 16 February 1863. READ, Thomas Cannell. http:/www.ancestry.co.uk

42. Deaths (CR) England. St Clement Danes, Middlesex. 24 September 1878. Cannell READ, Cannell.

43. Deaths announcements. (1878) Ipswich Journal. 1 October. READ, Cannell. p. If Collection: British Newspapers 1700-2017. www.findmypast.co.uk.

44. Boyer, G. R. (1997) Labour migration in southern and eastern England. European Review of Economic History. 1 (2). pp. 191-215. Digitalcommons.ilr.cornell.edu.

45. Baptisms (PR) England. Badingham, Suffolk. 26 February 1797. READ Joseph. St John the Baptist, Badingham, Suffolk

46. Burials (PR) England. Badingham, Suffolk. 18 May 1868. READ Joseph. St John the Baptist, Badingham, Suffolk.

47. Marriages (PR) England. St Mary, Woodbridge, Suffolk. 24 December 1814. READ, Joseph and PAULIN, Sarah. Suffolk Record Office.

48. Cooper, T. J. and Dodds, A. (2017) John Paulin and Landguard Fort; a forlorn search Suffolk Roots. 42(4). p. 323.

49. Suffolk Chronicle. (1825) Office of the Court for Relief of Insolvent Debtors. Suffolk Chronicle. 29 January. p. 2c. Collection: British Newspapers 1700-2017. www.find mypast.co.uk.

50. Bury \& Norwich Post. (1825) Insolvency. Bury \& Norwich Post, 2 March. p. 2b. Collection: British Newspapers 1700-2017. www.findmypast.co.uk

51. Ipswich Journal. (1821) Notice to creditors. Ipswich Journal. 5 May. p. 1b. Collection: British Newspapers 1700-2017. www.findmypast.co.uk.

52. Letter from the overseer of Framlingham concerning the settlement of David Read (1837) Badingham, Suffolk, Parish Records. FC101/G/20/3/21, Suffolk Record Office.

53. Baptisms (PR) England. Badingham, Suffolk. 28 May 1792. READ, Charles. St John the Baptist, Badingham, Suffolk.

54. Baptisms (PR) England. Badingham, Suffolk. 9 June 1829. READ, George. St John the Baptist, Badingham, Suffolk.

55. Deaths (CR) England. Greenwich East, London. 24 February 1917. READ, George Paulin.

56. Census. 1851. England, St Giles, Middlesex. HO107. PN 1508. FN 374. p. 45

57. Marriages (CR) England. St Giles, Middlesex. 7 May 1849. READ, George and PANK, Sarah.

58. Kitchin, Thomas. (1775) Reduced new pocket plan of the cities of London and Westminster. http://www.oldmapsonline.org/map/britishlibrary/ 007ZZZO000000004U00144000.

59. Baptisms (PR) England. Badingham, Suffolk. 8 July 1834. READ, William. St John the Baptist, Badingham, Suffolk.

60. Marriages (PR) England. St Dunstan and All Saints, Stepney, London. 26 January 1845. READ, Eliza and ARCHER, George. http://ancestry.co.uk.

61. Census. 1861. England. Hoxne, Suffolk. RG09. PN 1154. FN 38. p. 3.

62. Census. 1851. England. Samford, Suffolk. HO107. PN 1798. FN 42. p. 35.
63. Census, 1861. England Greenwich, London. RG09. PN 402. FN 12. p. 22.

64. Census (1861) England. Greenwich, London. RG09. PN 402. FN 10. p. 17.

65. Ludlow, Barbara J. Social conditions on Greenwich Marsh 1837-1901. https://green wichpeninsulahistory.wordpress.com/2013/08/03/social-conditions-on-greenwichmarsh-by-barbara-ludlow/.

66. Deaths (CR) England. Greenwich East, London 24 February 1917. READ, George Paulin.

67. Census. 1861. England. Greenwich, London. RG09. PN 402. FN 12. p. 22.

68. Deaths (CR) England. Greenwich East, London. 20 June 1900. READ, George Paul.

69. Births (CR) England. Greenwich East, London. 9 December 1858. READ, Joseph.

70. Kentish Mercury. (1891) Influenza and white lead poisoning. A report on the Coroner's Inquest. Kentish Mercury. 26 June. pp. 6c-7d.

71. Census. 1891. England. Plumstead, Woolwich. RG12. PN 541. FN 124. p. 1.

72. Barming Heath Lunatic Asylum, Maidstone, Kent. Case notes. MH/Md2/Ap25/48 p. 102 and MH/Md2/Ap25/65. p. 38. Kent Archives.

73. Barming Heath Lunatic Asylum, Maidstone, Kent. Case notes. MH/Md2/Ap25/48. p. 102. Kent Archives.

74. Deaths (CR) England. Greenwich East, London. 18 June 1891. READ, Catherine.

75. Kentish Mercury. (1891) Influenza and white lead poisoning. A report on the Coroner's Inquest. Kentish Mercury. 26 June. pp. 6c-7d.

76. Kentish Mercury. (1891) Influenza and white lead poisoning. A report on the Coroner's Inquest. Kentish Mercury. 26 June. pp. 6c-7d.

77. Kentish Mercury. (1891) Influenza and white lead poisoning. A report on the Coroner's Inquest. Kentish Mercury. 26 June. pp. $6 c-7 d$.

78. Worcester Chronicle. (1894) The dangers of white lead factories. Worcester Chronicle 3 February. p. 8a. Collection: British Newspapers 1700-2017. www.findmypast.co. uk.

79. Kentish Mercury. (1891) Influenza and white lead poisoning. A report on the Coroner's Inquest. Kentish Mercury. 26 June. pp. 6c-7d.

80. Spurgeon, A. (2012) The contribution of Women's Factory Inspectorate... to improvements in women's occupational health and safety. M.Phil thesis, University of Worcester. p. 42. http:/eprints.worc.ac.uk.

81. Spurgeon, A. (2012) The contribution of Women's Factory Inspectorate... to improvements in women's occupational health and safety. M.Phil thesis, University of Worcester. pp. 43-4. http:/eprints.worc.ac.uk.

82. Kentish Mercury. (1891) Influenza and white lead poisoning. A report on the Coroner's Inquest. Kentish Mercury. 26 June. pp. 6c-7d.

83. Kentish Mercury. (1891) Influenza and white lead poisoning. A report on the Coroner's Inquest. Kentish Mercury. 26 June. pp. 6c-7d.

84. Spurgeon, A. (2012) The contribution of Women's Factory Inspectorate... to improvements in women's occupational health and safety. M.Phil thesis, University of Worcester. p. 41. http:/eprints.worc.ac.uk.

85. Kentish Mercury. (1891) Influenza and white lead poisoning. A report on the Coroner's Inquest. Kentish Mercury. 26 June. pp. 6c-7d.

86. Kentish Mercury. (1891) Influenza and white lead poisoning. A report on the Coroner's Inquest. Kentish Mercury. 26 June. pp. 6c-7d.

87. Births (CR) England. Greenwich, London. 18 July 1887. READ, Frederick

88. Births (CR) England. St Clement Danes, Middlesex. 24 August 1884. READ, Joseph.

89. Barming Heath Lunatic Asylum, Maidstone, Kent. Case notes. MH/Md2/Ap25/48, p. 102 and MH/Md2/Ap25/65. p. 38. Kent Archives.

90. Greenwich Workhouse Infirmary. Registers. READ, Joseph. Religious creed register 1884-1894. GBG/221/004. Admissions and discharge register. 1884-1894. GBG/ 220/001. London Metropolitan Archives.

91. Deaths (CR) England. Greenwich East, London. 9 September 1892. READ, Joseph.

92. Deaths (CR) England. Greenwich East, London. 9 September 1892. READ, Joseph.

93. Barming Heath Lunatic Asylum, Maidstone, Kent. Case notes. MH/Md2/Ap25/48. p. 102. Kent Archives.

94. Deaths (CR) England. Greenwich East, London. 20 June 1900. READ, George Paul.

\section{ABOUT THE AUTHOR}

Trevor J. Cooper is a former lecturer and tutor. He has contributed to the journals of the Oxfordshire, Suffolk, Cornwall and Sussex family history societies.

Email: trevor.cooper5@btopenworld.com

http://orcid.org/0000-0002-7075-9923 